ISSN: 1858-4837; E-ISSN: 2598-019X

Volume 15, Nomor 2 (2020),

https://jurnal.uns.ac.id/region

DOI: $10.20961 /$ region.v15i2.31960

\title{
Strategi bermukim Suku Bajo di Desa Mola, Kabupaten Wakatobi
}

\author{
Reside strategy of Bajo Ethnic in Mola Village, Wakatobi Regency
}

\author{
L M Eryano ${ }^{1}$, Sudaryono ${ }^{1}$, dan D A Iskandar ${ }^{1}$ \\ ${ }^{1}$ Departemen Teknik Arsitektur dan Perencanaan, Fakultas Teknik, UGM
}

Corresponding author's email: musyafir.laode@gmail.com

\begin{abstract}
Abstrak. Desa Mola merupakan salah satu permukiman suku Bajo yang berada di Kepulauan Wakatobi yang memiliki kepadatan cukup tinggi dan berada di pesisir Mandati yang merupakan bagian dari kawasan perkotaan Wangi-Wangi. Perkembangannya permukiman suku Bajo di Desa Mola yang cukup pesat dikhawatirkan akan menciptakan konflik antara masyarakat yang ada di darat dengan suku bajo terkait pemanfaatan laut sebagai tempat bermukim yang di tuding menguntungkan pihak suku Bajo. Penelitian ini bertujuan untuk mengetahui seperti apa strategi bermukim suku Bajo di Desa Mola yang merupakan wilayah adat orang darat dan apakah strategi tersebut berpotensi menghasilkan konflik. Penelitian ini menggunakan metode induktif-kualitatif dengan pendekatan fenomenologi yang dalam tahapannya melalui proses grandtour, wawancara mendalam di Desa Mola. Analisa data dilakukan dengan cara kualitatif untuk menjelaskan fenomena yang terjadi terkait ruang, kegiatan dan pelaku yang ada di Desa Mola. Hasil dari penelitian ini menunjukan bahwa strategi Suku Bajo dalam bermukim yaitu melalui tata kelola lahan di laut yang diatur oleh lembaga adat Sara Mandati sebagai perwakilan masyarakat yang ada di darat melalui pemberian izin dan rekomendasi terhadap kepemilikan lahan dan pembangunan di laut serta adanya pemberian sanksi terhadap pelanggaran dilakukan. Selain itu, pengelolaan terhadap pemanfataan laut sebagai tempat bermukim Suku Bajo oleh Sara Mandati tidak berpotensi menghasilkan konflik karena adanya ikatan sejarah serta adanya hubungan kelembagaan.
\end{abstract}

Kata Kunci: Bajo; Strategi Bermukim; Tata Kelola Lahan

Received: July 10, 2019; Accepted: July 31, 2019; Available online: July 31, 2020

Copyright $\odot$ 2020, REGION: Jurnal Pembangunan Wilayah dan Perencanaan Partisipatif 


\begin{abstract}
Mola Village is one of the Bajo settlements located in the Wakatobi archipelago, which has a high density, and located on the coast of Mandati which is part of the Wangi-Wangi urban area. The rapid development of the Bajo ethnic's residence in Mola village is feared to create a conflict between the community that exists on land and Bajo ethnic related to the use of the coastal sea as a place to settle which was alleged to benefit the Bajo ethnic. This study aims to find out what the Bajo ethnic residence strategy is like in Mola Village, which is the customary area of people living on land, and whether the strategy has the potential to cause conflict. This study uses an inductive-qualitative method with a phenomenological approach which is through the grandtour process and in-depth interviews. Data analysis is done in a qualitative way to explain the phenomena that occur which related to space, activities and actors in Mola Village. The results of this study show that the strategy of the Bajo ethnic in settling is through the management of land in the coastal sea which is regulated by the Sara Mandati customary institution as a representative of the community on land. Customary institutions regulate the granting of permits and recommendations on land ownership and development in the coastal sea as well as sanctions for violations committed. In addition, the management of the use of the coastal sea as a place of residence for the Bajo ethnic by Sara Mandati does not have the potential to generate conflict because of the historical ties and institutional relationships.
\end{abstract}

Keywords: Bajo; Land Management; Reside Strategy

\title{
1. Pendahuluan
}

Suku Bajo dikenal juga sebagai suku laut, mereka menggantungkan hidupnya dari laut dan memiliki kehidupan yang tak pernah jauh dari laut. Banyak orang yang mengatakan bahwa Suku Bajo selalu identik dengan perahu, dan permukiman di atas air laut sebab dahulu mereka hanya tinggal di atas perahu dan mengembara/hidup berpindah-pindah dari satu tempat ke tempat yang lainnya (seanomedic). Kemudian kebiasaan hidup berpindah tergantikan dengan budaya bermukim menetap dengan membangun rumah di atas perairan/laut dangkal.

Perubahan pola hidup orang Bajo dari laut untuk kemudian menetap dan membuat permukiman di suatu tempat, menyebabkan mereka mengalami perubahan nilai-nilai sosial yang dianut. Menurut Suyuti [1] mengungkapkan bahwa perubahan konsep permukiman dari kehidupan di laut lepas kemudian tinggal di suatu tempat/daratan merupakan usaha untuk menjustifikasi kehidupan laut dan darat melalui suatu perspektif adaptasi dengan menempatkan perubahan budaya sebagai bagian dari usahanya untuk beradaptasi terhadap lingkungannya.

Saat ini permukiman Suku Bajo di sepanjang perairan Kepulauan Wakatobi merupakan salah satu permukiman dengan jumlah populasi Suku Bajo terbesar di Indonesia [2]. Sebaran komunitas Bajo di Wakatobi tersebar di beberapa pulau yaitu di Pulau Wangi-Wangi (Bajo Mola), Pulau Kaledupa (Bajo Sampela dan Bajo Mantigola), (Bajo Lohoa) dan Pulau Tomia (Bajo Lamanggau). Selain Suku Bajo Kepulauan Wakatobi sebagai bagian dari wilayah 
Kesultanan Buton di huni oleh etnis Buton-Wakatobi sebagai suku asli yang mendiami pulaupulau yang ada yang terbagi atas beberapa kelompok masyarakat adat.

Desa Mola merupakan salah satu permukiman Suku Bajo yang ada di Pulau Wangi-Wangi dengan luas sebesar \pm 32 ha dan jumlah populasi di Desa Bajo Mola sebesar 7.779 jiwa [3-4] menjadikan desa ini sebagai salah satu konsentrasi Suku Bajo terbesar di Indonesia. Letak Desa Mola berada di sisi selatan Pulau Wangi-Wangi yang menjadi lokasi ibukota kabupaten tepatnya berada di perairan Mandati yang merupakan bagian dari wilayah masyarakat adat Mandati sebagai salah satu dari tiga masyarakat adat yang menguasai Pulau Wangi-Wangi.

Pada perkembangannya Desa Mola sebagai perkampungan Bajo di wilayah perairan Mandati membuat kawasan ini memiliki nilai lebih. Hal tersebut didasari oleh letak perkampungan yang berada di kawasan perkotaan Wangi-Wangi dan dekat dengan ibukota kabupaten yang menjadi pusat-pusat kegiatan, selain itu kondisi wilayah perairan yang potensial untuk dijadikan lokasi permukiman tersedia cukup luas. Kemudahan beraktivitas dan lengkapnya sarana dan prasarana pendukung yang ada di Desa Mola sebagai permukiman di atas air membuat penguasaan atas lahan di lautan menjadi bergitu masif. Hal ini ditambah dengan kemudahan memiliki lahan di lautan dan aktivitas jual beli terhadap lahan maupun bangunan di lautan menyebabkan kecemburuan terhadap masyarakat yang ada di darat.

Wilayah daratan yang telah memiliki aturan jelas melalui peraturan zonasi kawasan membuat masyarakat yang ada di darat tidak bisa membuka lahan sebagai kawasan permukiman maupun perkebunan dan hal ini berbanding terbalik kondisinya dengan masyarakat Bajo yang tinggal di lautan yang belum memiliki aturan yang jelas. Hal ini dikhawatirkan dapat memicu konflik antara masyarakat adat yang ada di darat sebagai penghuni asli dari Pulau Wangi-Wangi dengan masyarakat Bajo sebagai pendatang. Tujuan dalam penelitian ini untuk menggambarkan seperti apa strategi bermukim masyarakat Bajo di Desa Mola yang merupakan wilayah adat orang darat dan apakah strategi bermukim tersebut berpotensi menghasilkan konflik. Desa Mola sebagai perkampungan Suku Bajo dapat dilihat pada Gambar 1.

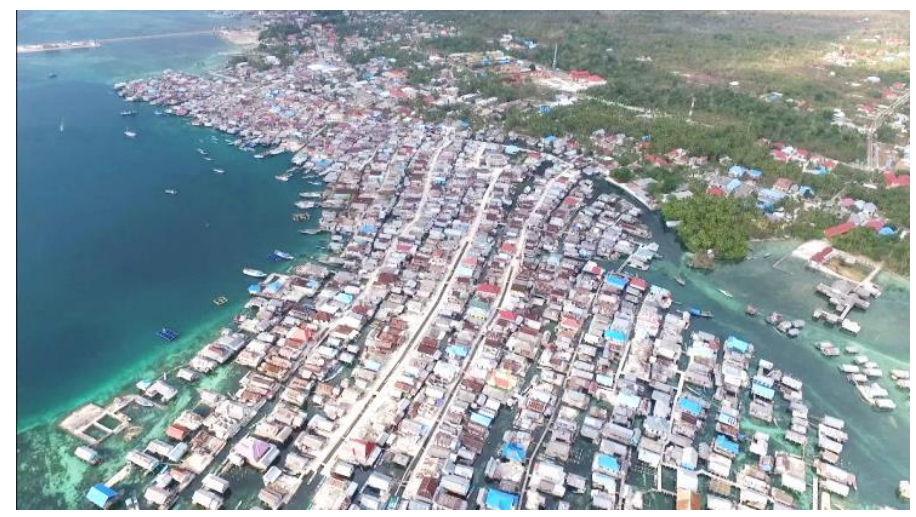

Gambar 1. Desa Mola sebagai perkampungan Suku Bajo. 


\section{Metode}

\subsection{Pendekatan penelitian}

Metode penelitian yang digunakan dalam penelitian ini adalah induktif-kualitatif dengan pendekatan fenomenologi. Penelitian kualitatif adalah penelitian yang bermaksud untuk memahami fenomena tentang apa yang dialami oleh subyek penelitian, misalnya perilaku, motivasi, tindakan dan lain-lain secara holistik dan dengan cara deskripsi dalam bentuk katakata dan dibahas pada suatu konteks khusus yang alamiah dan dengan memanfaatkan berbagai metode alamiah [5]. Lebih lanjut disebutkan juga bahwa penelitian kualitatif dapat digunakan untuk menelaah suatu latar belakang misalnya tentang motivasi, peranan, nilai, sikap dan persepsi [5]. Studi feneomenologi menekankan pada fenomena yang akan diekplorasi berdasarkan sudut pandang konsep atau ide tunggal dimana dilakukan ekplorasi fenomena pada kelompok individu terhadap pengalamannya terkait dengan suatu fenomena.

Metode analisis yang digunakan dalam penelitian ini adalah analisis deskriptif kualitatif. Inti analisa kualitatif terletak pada tiga proses yang terkait, yaitu mendeskripsikan fenomena, mengklasifikasikannya dan melihat bagaimana konsep yang muncul saling terkait satu dengan yang lain [5]. Proses analisis ini dilakukan mulai dari unit-unit informasi yang diperoleh melalui kegiatan observasi dan wawancara mendalam. Hal ini dimaksudkan untuk membuat kategorisasi data yang dapat terdiri dari banyak sumber dan sehingga menjadi suatu tema. Tema-tema yang muncul kemudian dikelompokkan berdasarkan kesamaan substansinya menjadi konsep. Menurut Bungin [6], wawancara mendalam secara umum adalah proses memperoleh keterangan tujuan penelitian dengan cara tanya jawab sambil bertatap muka antara pewawancara informan atau orang yang diwawancarai, dengan atau tanpa menggunakan pedoman wawancara. Lebih lanjut Putra [7] menambahkan bahwa dalam pendekatan penelitian fenomonologi memang wawancara mendalam memiliki kedudukan yang penting dan sentral. Namun, pengamatan, FGD, FGI, dan analisis dokumen tetaplah digunakan sesuai kebutuhan.

\subsection{Unit amatan dan unit analisis}

Unit amatan dari penelitian ini yakni ruang (permukiman), pelaku, kegiatan, objek, perbuatan, dan kejadian atau peristiwa yang ada di Desa Mola, Kabupaten Wakatobi yang meliputi pemanfaatan laut sebagai tempat bermukim. Unit analisisnya berupa ruang, kegiatan dan pelaku yang ada di Desa Mola.

\subsection{Sumber data}

Sumber data diperoleh melalui observasi secara langsung dan pengambilan dokumentasi keadaan di Desa Mola serta melakukan wawancara mendalam (in-depth Interview) terhadap berbagai narasumber. Pemilihan narasumber dilakukan pada orang-orang tertentu yang dinilai menguasai permasalahan (purposive sampling) yang selanjutnya akan dilanjutkan secara bergulir (snowball) pada daerah penelitian terutama yang menjadi implikasi spasial. Dengan dasar teori kejenuhan (tidak ada lagi tambahan data yang dapat menambah wawasan untuk pertanyaan penelitian) ditentukan sebagai ukuran sampel purposive [6]. 
Sehingga, dalam penelitian ini informan yang dianggap akan berperan banyak yakni tokoh adat Sara Mandati, tokoh masyarakat Bajo, serta masyarakat Bajo sebagai penghuni permukiman Bajo di Desa Mola. Narasumber penelitian dapat dilihat pada Tabel 1.

Tabel 1. Narasumber penelitian.

\begin{tabular}{ll}
\hline Aspek & Status \\
\hline Kelembagaan & Lembaga Adat Sara Mandati \\
Masyarakat Bajo & 18 Responden Tokoh dan Warga Bajo \\
Birokrasi & Pemerintah Desa \\
\hline
\end{tabular}

\section{Hasil penelitian dan pembahasan}

\subsection{Temuan tema-tema empiris}

3.1.1 Sejarah orang Bajo di Desa Mola. Orang Bajo di Desa Mola bukanlah penduduk asli yang mendiami Pulau Wangi-Wangi, mereka merupakan pendatang dari Pulau Kaledupa.

"Sejarah kedatangan masyarakat Suku Bajo yang tinggal di Desa Mola sebagian besar berasal dari Desa Mantigola di Pulau Kaledupa yang pada tahun 1950-an melakukan perpindahan ke Pulau Wangi-Wangi dikarenakan mereka merasa tidak aman dan terancam yang diakibatkan oleh gangguan dari kelompok DI/TII" [8].

Pada awal kedatangannya mereka tidak menempati Desa Mola yang sekarang ini mereka mereka tempati, akan tetapi mereka menempati wilayah Ogu yaitu pesisir utara dari Pulau Wangi-Wangi. Tapi di tempat itu kehidupan orang Bajo jauh dari kata aman. Hal ini akibat dari keadaan lingkungan di pesisir Ogu di Pulau Wangi-Wangi yang merupakan wilayah terbuka yang langsung menghadap ke laut banda, wilayah di perairan Ogu sering ditempa badai dan gelombang laut. Proses untuk pindah ketempat baru juga melalui tahapan yang panjang.

"...Sebelumnya orang Bajo yang datang dari Pulau Kaledupa ini tinggal di pesisir Wanci tapi di sana angin dan ombak sering merusak rumah kemudian orang tua kita dulu meminta izin kembali dengan pihak Sara (dewan adat) untuk tinggal di pesisir Mandati" [9].

"...Setelah melakukan negosiasi yang cukup lama dengan pihak Sara dan sanggup menerima peraturan yang ditetapkan pihak Sara, barulah orang Bajo dipersilahkan untuk menempati laut dan membangun permukiman di sepanjang Pantai Wanci dan Mandati" [8].

Dari uraian di atas diketahui bahwa status dalam kelompok sosial dalam masyarakat adat yang ada di Pulau Wangi-Wangi menempati urutan paling bawah dikarenakan masyarakat Bajo sebagai pendatang dan tidak memiliki hak atas lahan di Pulau Wangi-Wangi, sehingga masyarakat Bajo wajib mentaati segala aturan yang dikeluarkan oleh masyarakat adat. 
3.1.2 Proses kepemilikan atas lahan dan bangunan di laut. Kepemilikan atas lahan di lautan juga hampir sama prosesnya dengan yang ada pada masyarakat di darat yaitu melalui warisan maupun proses jual beli. Untuk jual beli lahan di tengah perkampungan tidak memiliki hambatan dari masyarakat adat yang ada di darat akan tetapi beda dengan wilayah yang baru dibuka sebagai permukiman, hal tersebut sangat dilarang oleh masyarakat adat yang ada di darat dikarenakan mereka hanya diberikan hak atas pemakaian bukan untuk mendapatkan keuntungan ekonomi.

Adapun dalam prosesnya kepemilikan lahan atau tempat di laut dibagi menjadi dua masa, yaitu;

- Pada saat tempat atau laut masih luas dan belum ada intervensi dari lembaga adat/ Sara Mandati. Ini berlangsung pada awal terbentuknya permukiman Suku Bajo di Desa Mola, hal ini dikarenakan lautan atau perairan dangkal yang ada masih cukup luas dengan jumlah penduduk yang masih sedikit. Proses kepemilikan tempat di masa itu hanya dengan meminta izin dengan penghuni awal yang ada di dekat tempat tersebut ataupun langsung dengan memberi tanda kepemilikan pada tempat tersebut.

"Dulu masih bebas kita membangun disini karena masih luas, kita hanya minta

izin saja dengan orang yang dekat dengan tempat kita membangun" [10].

- Aktivitas kepemilikan lahan di laut sebelum adanya intervensi dari lembaga adat membuat beberapa dari masyarakat Bajo memiliki lahan yang sangat luas di wilayah perairan Mandati, kemudahan untuk memiliki lahan di laut dengan hanya meminta izin dan memberi tanda di dasar laut menggunakan batu yang diikatkan kain atau tali berwarna sebagai batas atas kepemilikan lahan lahan di laut menyebabkan semakin meluasnya area permukiman masyarakat Bajo.

- Pada saat lembaga adat mulai memperkuat kembali kedudukannya terhadap pengelolaan wilayah laut di Desa Mola. Hal ini dikarenakan banyaknya terjadi aktivitas jual beli lahan di laut oleh masyarakat Bajo, sehingga lahan yang ada di laut diatur pemanfaatannya oleh lembaga adat yang ada di darat.

"Kita sekarang kalau mau bikin rumah atau fasilitas umum harus seizin Sara itu aturannya Sara sekarang yang sebelumnya tidak seperti itu" [11].

Kepemilikan atas lahan di laut yang di atur oleh Sara Mandati melalui pemberian hak atas lahan di laut melalui hibah maupun izin pakai. Cara ini dilakukan terhadap lahan yang berada di wilayah terluar dan belum terbangun di Desa Mola, hal ini dilakukan untuk mengendalikan bertambah luasnya permukiman masyarakat Bajo di laut.

3.1.3 Status atas lahan dan bangunan di laut. Status kepemilikan lahan dan bangunan di Desa Mola ada yang merupakan hak milik pribadi dan hak pakai terhadap Sara Mandati. Status kepemilikan lahan di Desa Mola yang merupakan milik pribadi dibuktikan dengan adanya Sertifikat Hak Milik yang dikeluarkan oleh Badan Pertanahan Negara sebagai lembaga negara yang ditunjuk untuk menerbitkan sertifikat tanah di Indonesia. Pada prosesnya kepemilikan atas sertifikat hak milik atas lahan yang ada di Desa Mola diterbitkan 
hanya pada lahan di laut yang memiliki timbunan di atas laut (telah menjadi daratan/hasil reklamasi) atau status lahannya jelas dan terlihat di atas laut. Untuk lautan yang belum memiliki timbunan lahannya masih merupakan milik masyarakat adat yang ada di darat dan masyarakat Bajo diberikan hak pakai terhadap lautan tersebut.

Selain kepemilikan atas lahan yang dibuktikan oleh sertifikat hak milik maupun hak pakai juga terdapat kepemilikan atas bangunan yang juga dibuktikan oleh surat kepemilikan bangunan yang dikeluarkan oleh pemerintah desa. Bangunan ini merupakan bangunan yang terbangun di atas laut yang belum memiliki timbunan (daratan hasil reklamasi) dan hanya berdiri di atas tiang kayu maupun tiang beton. Adapun lahan sebagai tempat tinggal merupakan hak pakai dari masyarakat adat yang tidak dapat diperjualbelikan. Adanya sertifikat atas kepemilikan tanah dan surat kepemilikan atas bangunan di atas laut memberikan kemudahan bagi warga dalam mendapatkan modal usaha dengan menggunakan surat-surat kepemilikan tersebut sebagai jaminan. Lahan tertimbun dan lahan perairan dapat dilihat pada Gambar 2.
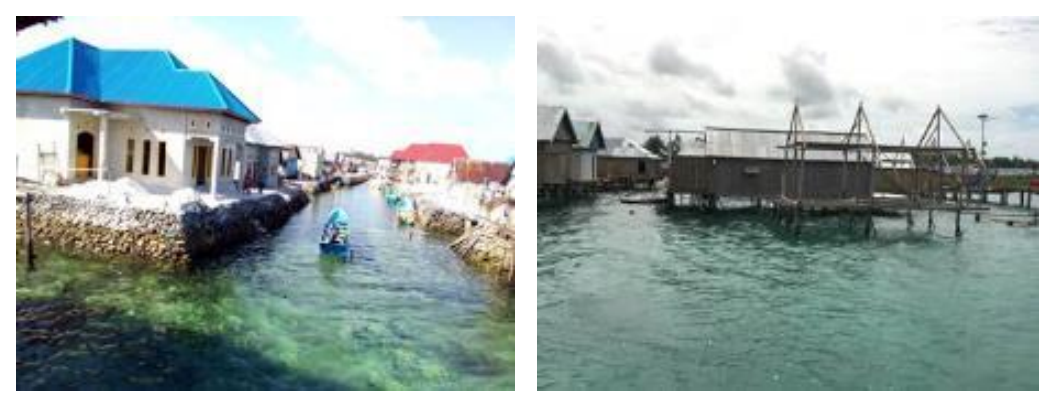

Gambar 2. Lahan tertimbun dan lahan perairan.

3.1.4 Ketersediaan dan pembangunan infrastruktur sebagai simbol di laut. Ketersediaan prasarana sebagai pendukung aktivitas bermukim masyarakat Bajo cukup lengkap baik yang masih berupa bangunan semi permanen maupun bangunan permanen yang telah dibangun pemerintah. Sarana pendukung yang ada di antaranya, kantor desa, sarana pendidikan (TK, SMP dan SMA), sarana kesehatan (Poskesdes), dan Masjid yang tersebar di beberapa tempat di Desa Mola yang lokasinya berada di tengah-tengah permukiman sehingga memudahkan diaksesnya fasilitas tersebut oleh masyarakat Bajo. Adapun prasarana pendukung yang tersedia di Desa Mola yaitu jaringan air bersih, septic tank komunal maupun setempat, jaringan listrik PLN/solar cell, jalan dan jembatan titian serta kanal sebagai jalur perahu masyarakat Bajo. Pembangunan infrastruktur di laut sebagai upaya peningkatan kualitas hidup masyarakat Bajo yang masih tetap tinggal dan bertahan di laut. Dalam setiap pembangunan infrastruktur di laut selalu melibatkan peran lembaga adat Sara Mandati, pemerintah desa dan tokoh-tokoh dalam masyarakat Bajo. Hal tersebut merupakan upaya menempatakan bangunan tersebut sebagai simbol atau tanda terhadap wilayah-wilayah yang ada di lautan. Selain itu, pembangunan infrasturktur yang ada memperhatikan fungsi kemudahan beraktivitas. Adanya batas yang jelas di lautan memudahkan pengarahan dan pengendalian terhadap perkembangan permukiman masyarakat Bajo. Sarana dan prasarana sebagai simbol/tanda di laut dapat dilihat pada Gambar 3. 

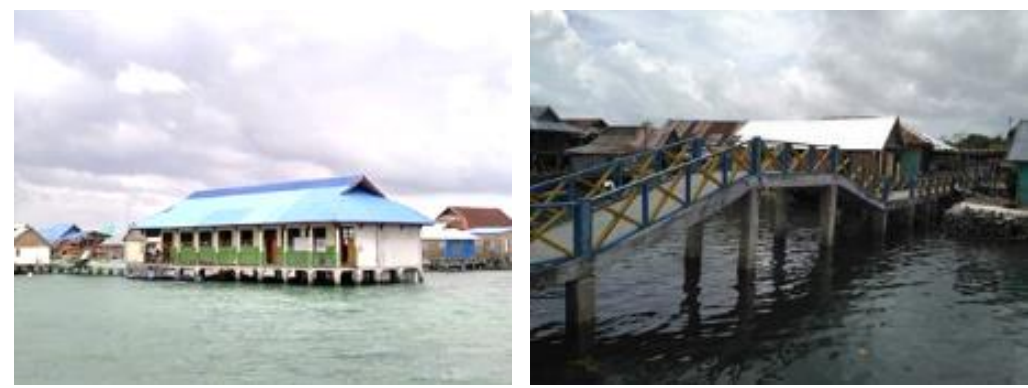

Gambar 3. Sarana dan prasana sebagai simbol/tanda di laut.

3.1.5 Konsensus masyarakat Bajo dengan Sara Mandati tentang batas desa. Di masa lalu terdapat aturan yang jelas mengenai batas permukiman masyarakat Bajo di Desa Mola dengan orang darat. Masyarakat Bajo diberikan keleluasaan memiliki tempat di lautan dan dilarang membangun di daratan begitu pula sebaliknya. Pada perkembangannya banyak dari orang darat yang tinggal di pesisir Mandati membangun bangunannya menjorok ke arah laut dan menambah luas kepemilikan tanahnya dengan menimbun lautan. Di lain pihak banyak pula dari masyarakat Bajo juga yang telah menimbun lautan sebagai tempat tinggalnya sehingga telah menyatu dengan daratan. Sehingga dibutuhkan upaya dari dewan adat dan masyarakat Bajo untuk mempertegas batas-batas desa untuk menghidari konflik yang mungkin tercipta.

Adanya kesepakatan yang baru mengenai batas desa yang kemudian dijadikan sebagai batas administrasi dari desa-desa yang ada di perkampungan Bajo Mola dengan tanda dan simbol dari bangunan yang terbangun di atas laut. Sedangkan untuk wilayah yang tidak memiliki tanda batas yang jelas dikarenakan masih berupa perairan berdasarkan kesepakatan bahwa bangunan terluar dari permukiman masyarakat Bajo merupakan batas desa yang tidak dapat diperluas lagi oleh masyarakat Bajo. Adanya batas-batas yang jelas pada saat ini memberikan kepastian terhadap wilayah yang dapat terbangun di darat maupun di lautan sehingga tidak menimbulkan konflik. Prasarana sebagai batas desa di laut dapat dilihat pada Gambar 4.
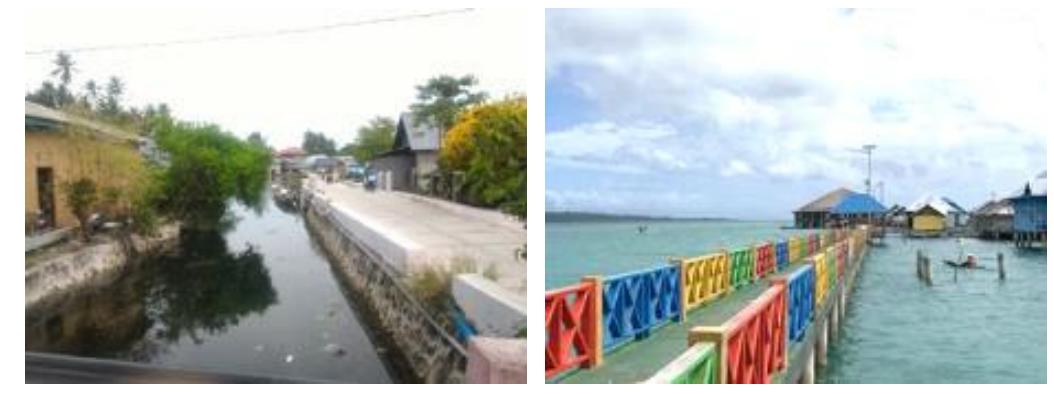

Gambar 4. Prasana sebagai batas desa di laut.

3.1.6 Intervensi lembaga adat Sara Mandati di Desa Mola. Lautan sebagai tempat bermukim maysrakat Bajo yang terletak di wilayah perairan Mandati merupakan bagian dari wilayah masyarakat adat Mandati dan lembaga adat Sara Mandati merupakan perwakilan masyarakat adat yang salah satu tugasnya mengatur mengenai pengelolaan atas hak ulayat 
atas wilayah adat. Kewenangan wilayah perairan di Desa Mola oleh lembaga adat Sara Mandati juga diakui oleh masyarakat Bajo yang ada di Desa Mola yang berdasarkan sejarah merupakan etnis pendatang di Pulau Wangi-Wangi.

Peran lembaga adat Sara Mandati terhadap perkembangan permukiman yang ada di Desa Mola yaitu melalui pemberian izin dan rekomendasi terhadap kepemilikan lahan dan pembangunan rumah tinggal di laut serta pembangunan sarana maupun prasarana pendukung.

"Kalau mau membangun di laut itu harus dengan seizin kita pihak Sara Mandati, supaya kita bisa lihat kelayakan tempatnya seperti apa dan mereka juga pasti bersurat kepada kita kalau ingin membangun"[12].

Pemberian izin dan rekomendasi ini diberikan pada warga yang ingin membangun pada wilayah-wilayah tertentu. Pemberian izin dan rekomendasi ini semata-mata untuk menghindari kepemilikan lahan yang luas di lautan atas individu masyarakat Bajo sehingga tidak dijadikan sebagai objek jual beli. Selain pemberian izin dan rekomendasi terhadap kepemilikan lahan dan pembangunan di laut terdapat pula sanksi bagi pelanggar yang tidak mengikuti aturan yang dibuat oleh Sara Mandati. Pemberian teguran dan pembongkaran terhadap bangunan di laut dapat dilakukan akibat pelanggaran yang dilakukan oleh masyarakat Bajo. Jembatan titian sebagai pengendali permukiman dapat dilihat pada Gambar 5.

"Kita sudah pernah tancapkan tiang-tiang rumah di lokasi itu karena tidak minta izin dengan Sara yang ada di darat dicabut sama mereka" [13].

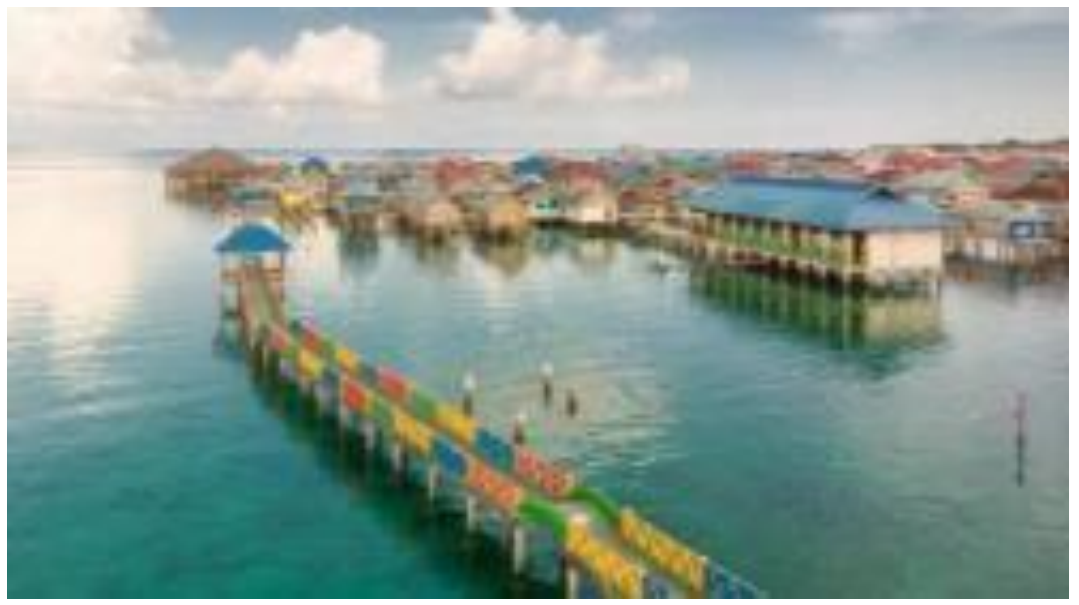

Gambar 5. Jembatan titian sebagai pengendali permukiman.

3.1.7 Paturu Ma Abal sebagai filosofi masyarakat Bajo Desa Mola. Masa lalu suku Bajo yang tinggal dan menetap secara berkelompok di perahu dan mengikuti arah arus kemana mereka akan dibawa dengan tidak melawan kehendak alam membuat mereka dapat bertahan di lautan lepas. Hal ini dikenal dalam Bahasa Bajo sebagai Paturu Ma Abal yang 
kemudian dijadikan pegangan hidup masyarakat Bajo dalam menjalani hidupnya. Nilai yang terkandung dalam filosofi tersebut terbawa hingga sekarang sehingga masyarakat Bajo di Desa Mola tidak memiliki masalah yang berarti dalam perkembangan komunitasnya.

Makna Paturu Ma Abal juga dapat berarti ikut-ikutan, utamanya dalam pengambilan keputusan dalam komunitas mereka, orang Bajo enggan menghadapi masalah sendirian oleh sebab itu mereka akan mengikuti keputusan yang diambil oleh mayoritas masyarakat Bajo yang diwakili oleh tokoh-tokoh masyarakat Bajo maupun forum-forum kelembagaan yang ada sehingga dalam penerapan terkait hasil keputusan dari forum tersebut tidak akan mengalami penolakan dari masyarakat Bajo.

\subsection{Konseptualisasi tema}

3.2.1 Tata kelola lahan di laut oleh Sara Mandati sebagai strategi bermukim masyarakat Bajo Desa Mola. Kebutuhan akan lahan di laut sebagai tempat bermukim masyarakat Bajo yang semakin besar membutuhkan pengelolaan agar tidak menciptakan konflik sosial dengan masyarakat darat. Lembaga adat Sara Mandati yang mempunyai kewenangan terhadap wilayah ulayat yang juga diakui oleh masyarakat Bajo mengambil peran sebagai pengelola pemanfataan laut sebagai tempat bermukim.

Stein [14] mengungkapkan bahwa instrumen pengaturan atau pengelolaan (regulatory tools) terdiri atas (1) pemintakatan (zonasi), yaitu pembagian wilayah menjadi zona-zona atau distrik-distrik tertentu menurut kemampuan lahan yang dimiliki, (2) perizinan lokasi, yaitu perizinan pembangunan atau kegiatan fungsional lain yang dimaksudkan untuk mengarahkan dan mengendalikan perkembangan pemanfaatan dan penggunaan lahan serta mengarahkan ke lokasi-lokasi yang tepat guna dari segi penyediaan sarana prasarana, dan (3) perizinan bangunan, yaitu izin untuk melaksanakan pembangunan fisik di atas lahan yang telah ditetapkan izin lokasinya.

Peran lembaga adat Sara Mandati terhadap pengelolaan lautan yaitu yang berfungsi mengeluarkan peraturan mengenai pemanfaatan lahan di laut melalui kebijakan arahan pengembangan wilayah permukiman baru, pemberian izin dan rekomendasi atas kepemilikan lahan di lautan sebagai tempat pembangunan rumah tinggal maupun sebagai tempat pembangunan sarana dan prasarana pendukung. Selain itu juga lembaga adat juga mempunyai peran sebagai pemberi sanksi terhadap pelanggaran yang dilakukan

Tata kelola lahan dan kepemilikan aset yang dilakukan dan disepakati oleh Sara Mandati, pemerintah desa maupun masyarakat Bajo terhadap laut sebagai tempat bermukim merupakan upaya masyarakat Bajo tinggal dan bermukim dengan nyaman sehingga tidak menimbulkan konflik dengan masyarakat yang ada darat. Selain itu pengakuan akan kepastian kepemilikan akan aset di lautan yang diakui oleh semua pihak dapat menjadi modal finansial untuk dijadikan sebagai modal usaha dalam menjalani kehidupan mereka. 
Lembaga adat Sara Mandati sebagai otoritas penguasa di wilayah adat menekankan adanya pemanfaatan yang berkeadilan dengan masyarakat yang ada di darat melalui penentuan wilayah yang dapat terbangun, pemberian izin dan rekomendasi serta kebijakan penempatan fasilitas yang dapat dijadikan sebagai simbol (batas desa).

\section{Kesimpulan}

Strategi bermukim masyarakat Bajo di Desa Mola melalui tata kelola atas kepemilikan lahan dan pembangunan di laut yang diatur oleh Sara Mandati (Lembaga Adat Mandati) sebagai perwakilan orang darat. Tata kelola atas kepemilikan lahan dan pembangunan di laut melalui pemberian izin dan rekomendasi terhadap pembangunan di laut melalui penunjukan terhadap lokasi penempatan atas pembangunan rumah maupun sarana dan prasarana serta pemberian sanksi atas pelanggaran yang dilakukan. Selain itu adanya pengakuan yang diberikan oleh masyarakat adat terhadap lahan di laut yang dibuktikan oleh adanya sertifikat atas lahan di laut maupun kepemilikan surat kepemilikan bangunan di laut .

Pengelolaan atas laut sebagai lahan bermukim orang Bajo yang diatur oleh Sara Mandati sebagai perwakilan dari orang darat juga tidak berpotensi menghasilkan konflik karena menghasilkan keputusan yang memuaskan bagi pihak masyarakat Bajo yang bermukim di laut maupun bagi orang darat, hal tersebut karena adanya ikatan sejarah serta hubungan kelembagaan antara pemerintah desa dan lembaga adat terkait pemanfaatan laut sebagai tempat bermukim.

Rekomendasi dalam penelitian ini yaitu : 1) Diperlukan pengaturan tentang permukiman di atas air dalam format peraturan daerah, agar sesuai dengan kondisi di daerah. Dengan demikian, dapat mengontrol kebijakan yang diambil oleh pemerintah daerah. 2) Dalam menetapkan kebijakan yang berhubungan dengan pemanfaatan ruang permukiman Desa Mola, pemerintah harus dapat berkerjasama dengan Dewan Adat utamanya terkait dengan penerbitan surat kepemilikan akan lahan maupun bangunan di laut, pemberian izin dan rekomendasi terhadap pembanguan di laut. Hal ini dikarenakan, pengakuan masyarakat Bajo terhadap Dewan Adat sebagai penguasa di wilayah tersebut.

\section{Referensi}

[1] Suyuti N 2011 Orang Bajo di Tengah Perubahan (Yogyakarta: Penerbit Ombak)

[2] Suryanegara E, Suprajaka dan Nahib I 2015 Perubahan Sosial Pada Kehidupan Suku Bajo: Studi Kasus di Kepulauan Wakatobi, Sulawesi Tenggara Jurnal BIG 171 pp 6778 Diakses dari https://adoc.tips/perubahan-sosial-pada-kehidupan-suku-bajostudi-kasus-di-kep.html

[3] Badan Pusat Statistik Kabupaten Wakatobi 2017 Wakatobi Dalam Angka Diakses dari https://wakatobikab.bps.go.id/publication/2017/08/11/4eae39242f474bb877d9af0 8/kabupaten-wakatobi-dalam-angka-2017.html pada 22-04-2017.

[4] Badan Pusat Statistik Kabupaten Wakatobi 2017 Wangi-Wangi Selatan Dalam Angka Diakses https://wakatobikab.bps.go.id/publication/2017/09/20/8bd82ef57f573cebb161a6a a/kecamatan-wangi-wangi-selatan-dalam-angka-2017.html pada 07-07-2020 
[5] Moleong L J 2006 Metodologi Penelitian Kualitatif (Bandung: PT. Remaja Rosdakarya)

[6] Bungin B 2010 Penelitian Kualitatif Komunikasi, Ekonomi, Kebijakan Publik dan IImu Sosial Lainnya (Jakarta: Kencana Prenada Media Group)

[7] Putra N 2013 Penelitian Kualitatif IPS (Bandung: PT. Remaja Rosdakarya)

[8] Udk 15 Agustus 2017 Komunikasi Personal

[9] Maj 15 Agustus 2017 Komunikasi Personal

[10] Cha 11 September 2017 Komunikasi Personal

[11] Yas 13 September 2017 Komunikasi Personal

[12] Aly 18 Agustus 2017 Komunikasi Personal

[13] Wah 25 Agustus 2017 Komunikasi Personal

[14] Stein J M 1993 Growth Management: The Planning Challenge of the 1990's (London: Sage Publication) DOI: 10.2307/143587 